\title{
The Aging Workforce Management in Business Sectors
}

\author{
Nhatphaphat Juicharoen ${ }^{1 *}{ }^{\oplus}$, and Suradetch Wangthong ${ }^{1}(\mathbb{C}$
}

Lecturer, School of Management Science, Sukhothai Thammathirat Open University, Thailand

* Corresponding author

(sutarat.jui@gmail.com)

Received: 20 October, 2020

Revised: 6 May, 2021

Accepted: 9 May, 2021

Published: 10 June, 2021

How to cite this paper:

Juicharoen, N., Wangthong, S. (2021). The aging workforce management in business sectors. Quest Journal of Management and Social Sciences, 3(1), 40-48.

\begin{abstract}
Background: Aging society affects good planning in workforce management for sustainable business running. Workforce management is not only the duty of human resources but also promotes the strategy for effective management.

Objectives: The objective of this study is to analyze the aging workforce management in business sectors.

Method: The research reviews relevant literature and, based on the evidence of theories about age-diverse management, creates a framework related to antecedent factors and the following factors. The testing applied the CBSEM model with a sample group of 300 respondents.
\end{abstract}

Result: The result found that planning "capacity in the workplace" and "knowledge management" are two factors that affect the potential corporate reputation efficiency of an organization significantly via "cultural value" and "social value" which were completely transformational.

Conclusion: The result of the study regarding the theory evidence and support research from overseas has a problem in applying to practice with an empirical result that differs locally. Therefore, the model needs to be verified with the local data, and develop a suitable model.

Keywords: workforce management, workforce, aging, business

Originality: This paper is original, and this has not been published in other publications. Similarly, no financial support has been received while working on this paper.

Paper Type: Research paper

JEL Classification: J21, M10 


\section{Introduction}

Workforce management in the future under population structure change is important at both the national and business levels. The country has realized that society steps into an aging society: more than seven percent of the total population is over 65 -year-old. Some countries have become aging societies such as European countries and Japan. It is predicted that, by 2050, the world population will completely become an aging society with more than $14 \%$ of 65 -year-old of the overall world population (Khan, et al, 2018). A study predicts that, by 2033, Thailand will have $25 \%$ retired people (United Nations, 2010). Many countries like Japan and Singapore cooperate between state and the entrepreneurs of business sectors and plan to handle the problems such as extended working life. However, such a strategy confront the problems of aging diversity conflict management, appropriate job design, knowledge retention, and knowledge sharing from the elderly group to the new generation of workers. Each aspect refers to processes and plans in many countries, on the other hand, the entrepreneur group in Thailand is a new concept. The government took it important as it is defined in the practice guideline of Human Resources Management in Elderly Dimension in Thailand.

One of the problems was to ensure building public health system to serve this group of people, even though, nowadays the health system of Thailand, particularly, of the elderly has been recently improved. The elderly people (after 55 years or 60 years i.e., after their retirement) can work using their knowledge and experience in supporting organizations to run effectively. The overseas research indicated that the elderly can serve as role-model for youngsters. The research identifies the following characteristics; 1) organizational loyalty, 2) working discipline, 3) working values as the value of life, not money, 4) social relation needed, and 5) knowledge (Angus \& Reeve, 2006). Therefore, risk management of the workforce and the study of organizational processes are the key factors for human resources management. Although it may be quite inconvenient and difficult to do it, the result could be positive in the long run. It is not as same as changing the production system with capital investment; the result would be visible in the long run (Barney, 1991).

The study therefore aims to study the level of using factors of age-diverse workforce management which consist of planning strategies of age-diverse workforce management, high work performance workplace management, and knowledge management with age-diverse workforce management in an organization. To study the level of mediator variable, effective value, culture value, and social value and to study the level of result factors, level of corporate reputation expectation.

Further part of this paper is organized as: second section includes literature review followed by research method in section three whereas, section four includes data analysis and result. Finally section five concludes the study.

\section{Review of Literature}

\section{Aging Workforce Management}

The Population Division, DESA, the United Nations (2010) reports that the population structure of the world is changing faster than ever before and the world population will have more elderly people in its history. The fast increase in the population of the elderly has both positive and negative (Loomes \& McCarthy, 2011) aspects. On its positive side (Ball et al., 2011), it is keeping intellectual capital (Streb \&Voelpel, 2010), and, on its negative side, this increase needs support for tangible resources in management, workplace, job description, environment for this group, etc. of people to work. Moreover, managing people of different age groups effectively is a challenge (Stam, 2009). The difference in people's age in the organization would make problems such as communication, ability in using technology, and value. If there was not good management, it would make the resistance of each group and turn to conflict (Cappelli, 2010). 


\section{Strategic Age-Diverse Workforce Management (SAWM)}

Strategic age-diverse workforce management is a process that an organization runs under the direct supervision of the highest level of entrepreneur or director, who is the representative of the business organization. In human resources management of an organization, the efficiency in organization appears as a goal, vision, and obligation, that defines the policies and working plans focusing on resources, in this case, age-diverse workforce management especially elderly people (Forester Research, 2012). In other viewpoints, aging workforce management is similar to disability workforce management that needs to design workplaces, facilities, building workplace environments including cooperation building between ages. The aging workforce management strategies have two aspects; 1) awareness training to the aging people to understand with modern technology, and 2) support consciousness of living together. Awareness training to aging people belongs to a traditional concept in human resources management as a part of the duty of the human resources management department in workforce management to control organization capital effectively (Frank, 2003). According to key principles in workforce management, human resources management works on three types of abilities: first, capability in prevision professional knowledge working skills in the future; second, the ability to choose professional with needed skills; and third, the ability to cooperate between an organization and its network.

One of the aspects of training focuses on a situation that makes trainee concern; if they lack this knowledge, the problem will appear in the future such as safety awareness; applying self-knowledge, and organization to prevent property and organization knowledge. Therefore, many organizations conduct training sessions on safety rules that a worker needs to know and the workers are conscious of taking care of the property of the organization. This is called security awareness. Supporting the consciousness of living together (ADM), the management follows the principle of the cooperative agediverse workforce, for example, building understanding, value sharing, and conflict management to enable the workers to avoid conflict, and support cultural values and collectivism.

\section{High Work Performance Workplace Management (HPWM)}

Physical management and workplace environment efficiency support the goal of business in creating value, enhancing workplace management. This needs a continuous balance in the management of human resources investment, process, physical resources, environment, and technology for support learning, increase workers' ability in working and building innovation, produce good quality of goods or having good service and impress customers from capacity beyond others (Mouritsen et al., 2001). High-performance environment management, the worker should trust each other, having a sense of power support in using their experience for better work, success work, happy and satisfied with work, effective work and using resources valuable, in case of a leader who could manage high-performance workplace affected to team building efficiency and organization success.

\section{Knowledge Management Age-Diverse Workforce (KMDW)}

Knowledge management is the process of knowledge building that was not in procedure such as knowledge of workers who learned directly or indirectly, such from practice, or from training or transferring the knowledge and skills from colleagues. The knowledge created in an organization is the intellectual capital, valuable property of the organization. Therefore, managing this property means retaining the knowledge and updating it by creating new knowledge and storing, sharing, and acquisition of knowledge (Beck 2009; Grubic-Nesic et al., 2014). Having a good relationship is good power of knowledge sharing both in physical and virtual communities (Bock\&Kim., 2002; Dholakia, 2005). The basic property of it depends on the role of exchange, even though, it is a different group. Each group has a different level of knowledge and a role of reciprocity. This makes it efficient knowledge management (Sole\& Applegate, 2000). Sharing knowledge with other individuals gets the 
benefit in long term (Henning-Thurau et al., 2010; Kim et al., 2008; Bennett \& Kottasz, 2000). The high-level employees such as directors in an organization are elderly and they get retirement shortly. In such a situation, organizations are not prepared to transfer knowledge from this group of people to the younger generation (Green, 2007).

Failure to transfer the knowledge affects the functioning of the organization because this knowledge could be important in organization strategic management (Cong \& Pandya, 2003), even the process is difficult. Knowledge management in an organization with aging people can become a significant corporate experience with high valuable (Hewitt, 2012; Henkens \& Schippers, 2012). In the present time, we can apply technology for effective knowledge management, though that requires highlevel leadership skills to be successful (Northouse, 2013). Achievement of high-level management of knowledge created by the experience of aging people is possible if that knowledge is efficiently transferred to the younger employees of the organization. This process enhances the employees' capacity and implicitly the capacity of the organization as a whole. It gives value in diversity management that adds economic value to the organization. Here, value refers to notions such as emotional value, pride, and honor that are valuable to individuals, the organization, and society at large. The age-diverse workforce management functions as a key to knowledge sharing, continuous support customer service continually, and building harmony in working cooperatively. The aging people help in joining idea with group Y (gen y) and group X (gen X) that support the potential corporate reputation of the organization (Paarlberg \& Perry, 2007).

\section{Potential Corporate Reputation (PCR)}

Potential corporate reputation meant the overall characteristic acknowledgment, each characteristic from each organization might affect economic, social, cultural, and environmental aspects of society. The acknowledgment might summarize in positive or negative aspects from the evaluation stakeholder (Fombrun et al., 1999). Corporate reputation was defined into 3 groups 1) state awareness evaluation, feeling of the overall of company base on the evaluation of social effect, 2) corporate reputation that evaluated belong to believe of acknowledgment that organization do and affect the public in economic, social, and previous environment, and 3) the meaning of corporate reputation in property point of view was intangible resources but finally can exchange to tangible resources (Van \& Blamer 1997; Mook 2013).

\section{Research Method}

This paper seeks to develop a planning model of an age-diverse workforce of aging worker dimension based on the review of relevant literature. This model is analyzed and checked with the data collected from a sample group of 300 business respondents selected from the service business, production business, trading business, and others such as retail. The sample was administered by applying a 5-point Likert scale questionnaire.

\section{Data Analysis and Results}

\section{Descriptive statistics}

The workforce retirement age was 60 years and that counted for $46 \%$ and others did not have a fixed age of retirement but depend on the discretion of directors and, usually, that was 60 and above. The interview sessions with the directors revealed that, if the worker was knowledgeable and having the ability to support business, they would extend working life, and the workers were adjusted to the job suitable for his/her age such as consultant even their age was over retirement. 
Table 1: Showing business characteristic and workforce age

\begin{tabular}{|c|c|c|c|}
\hline \multicolumn{2}{|c|}{ Variable } & \multirow{2}{*}{$\frac{\text { Frequency }}{70}$} & \multirow{2}{*}{$\frac{\text { Percent }}{23.33}$} \\
\hline Key Business & Goods production & & \\
\hline & Services & 157 & 52.33 \\
\hline & Agent & 67 & 22.33 \\
\hline & Others such Retail Shops & 6 & 2.00 \\
\hline \multirow[t]{4}{*}{ Length of Business Running } & $1-3$ years & 16 & 5.33 \\
\hline & 4-10 years & 80 & 26.67 \\
\hline & $11-20$ years & 94 & 31.33 \\
\hline & More than 20 years & 110 & 36.66 \\
\hline \multirow[t]{4}{*}{ Number of workers in the company } & $26-30$ workers & 116 & 38.67 \\
\hline & $31-50$ workers & 61 & 20.33 \\
\hline & 51-200 workers & 91 & 30.33 \\
\hline & More than 200 workers & 32 & 10.67 \\
\hline \multirow[t]{4}{*}{ Company retirement } & 55 years & 39 & 13.00 \\
\hline & 60 years & 137 & 45.67 \\
\hline & Over 60 years & 6 & 2.00 \\
\hline & $\begin{array}{l}\text { Not fixed, depend on } \\
\text { directors' discretion }\end{array}$ & 118 & 39.33 \\
\hline
\end{tabular}

Table 2: The mean level of study factors along with framework in each aspect

\begin{tabular}{lclll}
\hline \multicolumn{1}{c}{ Factors } & Mean & $\begin{array}{c}\text { Standard } \\
\text { Deviation }\end{array}$ & $\begin{array}{c}\text { Coefficient } \\
\text { of Variation }\end{array}$ & $\begin{array}{c}\text { Result } \\
\text { interpretation }\end{array}$ \\
\hline Strategic Age-Diverse Workforce Management & 3.821 & 0.956 & 0.250 & High \\
High Work Performance Workplace Management & 3.930 & 0.865 & 0.220 & High \\
Knowledge Management Age-Diverse Workforce & 3.864 & 0.987 & 0.255 & High \\
Management & & & & \\
Property Value & 3.799 & 0.909 & 0.239 & High \\
Culture Value & 3.884 & 0.932 & 0.240 & High \\
Social Value & 3.810 & 0.952 & 0.250 & High \\
Potential Corporate Reputation & 3.688 & 0.955 & 0.259 & High
\end{tabular}

The result of comparing factors used in planning management i.e., in strategic age-diverse workforce management (SAWM), high work performance workplace management (HPWM), and knowledge management age-diverse workforce (KMAD) found the scores very close. High work performance workplace management has the mean score at 3.930, the highest, the second factor has a close score in mediator variable, the social value has a more expanding level but high mean score, property value, and cultural value in factors of potential corporate reputation was only 3.688. On the other hand, the coefficient of variation was high at almost $26 \%$ that shows the difference of expanding of high expectation.

\section{Hypothesis Testing}

Model 1: Role model framework of business in planning to serve age-diverse workforce management in the context of an aging worker according to the literature review: 


\section{Figure 1: Hypothesis Testing}



The testing of what is the characteristic of PV, SV, and SV factors between independent factors SAWM, HPWM, and KMAD with dependent factor PCR, the result according to the following process (a) testing SAWM, HPWM, and KMAD significance influence to PCR and (b) testing influence the full model.

Testing influence of SAWM, HPWM, and KMAD on PCR

\section{Figure 2: Independent and Dependent Factors}

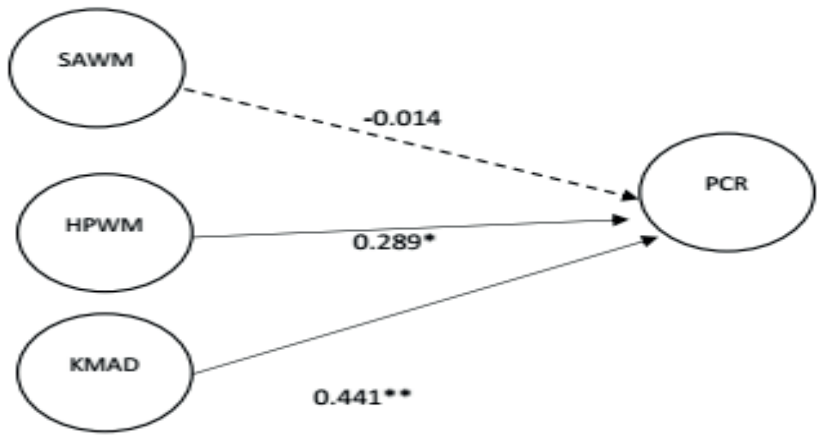

The testing result found that HPWM and KMAD have a significant influence on PCR. The testing of influence in both direct and indirect of SAWM, HPWM, and KMAD to PCR with mediator variable was PV, CV, and SV (The full model)

Figure 3: Factors and Correlation Coefficient $(* p=.05, * * p=0.01)$

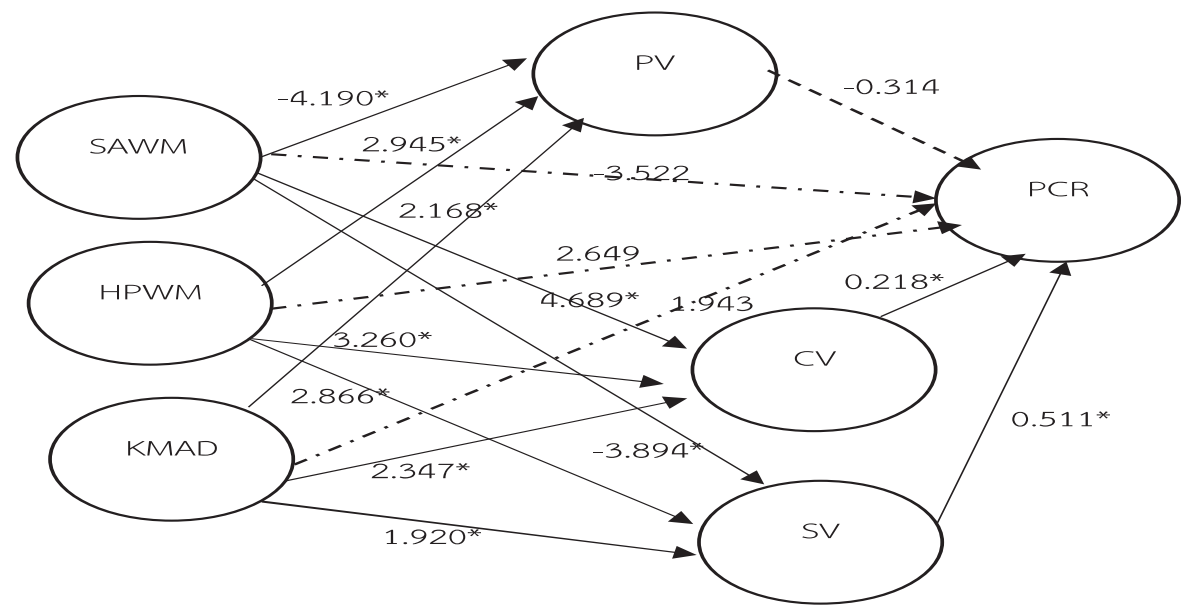


Figure 1 and Figure 2 indicates that HPWM and KMAD influence PCR directly. CV and PCR were serial effects of SAWM and SV; and PCR was a serial effect of SAWM, PV, and SAWM. From HPWM to PCR shows that CV, SV was complete mediator; PV was an effect of HPWM and from KMID to PCR shows that CV, SV was complete mediator; PV was an effect of KMAD.

Table 3: Coefficient, Standard deviation and T- statistic in model 2

\begin{tabular}{|c|c|c|c|c|c|c|c|c|}
\hline Relation & $\begin{array}{c}\text { Standard } \\
\text { Coefficient }\end{array}$ & T-statistic & Result & Relation & & $\begin{array}{c}\text { Standard } \\
\text { Coefficient }\end{array}$ & T-statistic & Result \\
\hline $\begin{array}{l}\text { SAWM }=> \\
\text { PV }\end{array}$ & $-4.190 *$ & -2.021 & Support & $\begin{array}{l}\text { HPWM = } \\
\text { PV }\end{array}$ & $=>$ & $2.945^{*}$ & 1.941 & Support \\
\hline $\mathrm{PV}=>\mathrm{PCR}$ & -0.314 & -0.352 & $\begin{array}{c}\text { Not } \\
\text { support }\end{array}$ & $\begin{array}{l}\text { HPWM = } \\
\text { PCR }\end{array}$ & & 2.649 & 0.265 & $\begin{array}{c}\text { Not } \\
\text { support }\end{array}$ \\
\hline $\begin{array}{l}\text { SAWM } \Rightarrow \\
\text { PCR }\end{array}$ & -3.522 & -0.245 & $\begin{array}{c}\text { Not } \\
\text { support }\end{array}$ & $\begin{array}{l}\text { HPWM = } \\
\text { CV }\end{array}$ & $=>$ & $3.260 *$ & 1.926 & Support \\
\hline $\begin{array}{l}\text { SAWM }=> \\
\mathrm{CV}\end{array}$ & -4.689 & $-2.025^{*}$ & Support & $\begin{array}{l}\mathrm{HPWM}= \\
\mathrm{SV}\end{array}$ & $=>$ & $2.866^{*}$ & 2.002 & Support \\
\hline $\mathrm{CV}=>\mathrm{PCR}$ & $0.218^{*}$ & 1.659 & Support & $\begin{array}{l}\text { KMAD = } \\
\text { PV }\end{array}$ & $\Rightarrow$ & $2.168 *$ & 2.370 & Support \\
\hline $\begin{array}{l}\text { SAWM }=> \\
\text { SV }\end{array}$ & $-3.894 *$ & -1.991 & Support & $\begin{array}{l}\text { KMAD = } \\
\mathrm{CV}\end{array}$ & $=>$ & $2.347 *$ & 2.299 & Support \\
\hline $\mathrm{SV}=>\mathrm{PCR}$ & $0.511 *$ & 1.962 & Support & $\begin{array}{l}\text { KMAD = } \\
\text { SV } \\
\text { KMAD = } \\
\text { PCR }\end{array}$ & $\begin{array}{l}\Rightarrow> \\
=>\end{array}$ & $1.920 *$ & 2.221 & $\begin{array}{c}\text { Support } \\
\text { Not } \\
\text { support }\end{array}$ \\
\hline
\end{tabular}

The conclusion shows HPVM and KMAD indirectly influence via CV and SV to PCR while SAWM is not directly affected by the PCR, and PV, CV, and SV were multiple effects. It shows that planning of strategic age-diverse workforce is not positive support but a negative one that differs from the study of Frank \& Rusco (2003); Hedge \& Lammlein (2006) and Naegele \& Walker (2006) that found "strategies of different managing" was a positive influence to "building cost and value".

Table 4: Direct and Indirect Influence and Total

\begin{tabular}{ccccccc}
\hline & SAWM & HPWM & KMAD & PV & CV & SV \\
\hline PV & $-4,190$ & 2.945 & 3.260 & NA & NA & NA \\
DE & NA & NA & NA & NA & NA & NA \\
IE & -4.190 & 2.945 & 3.260 & NA & NA & NA \\
TE & & & & & \\
CV & -4.689 & 3.260 & 2.347 & NA & NA & NA \\
DE & NA & NA & NA & NA & NA & NA \\
IE & -4.689 & 3.260 & 2.347 & NA & NA & NA \\
TE & & & & & NA \\
SV & -3.894 & 2.865 & 1.920 & NA & NA & NA \\
DE & NA & NA & NA & NA & NA & NA \\
IIE & -3.894 & 2.865 & 1.920 & NA & & \\
TE & & & & & 0.218 & 0.511 \\
PCR & -3.552 & 2.649 & 1.945 & -0.314 & NA & NA \\
DE & -1.696 & 1.251 & 0.812 & NA & 0.218 & 0.511 \\
IE & -5.248 & 3.900 & 2.767 & -0.314 & & \\
TE & & & & & \\
\hline
\end{tabular}


The result from Table 4 reveals that the overall influence of factors, Strategic Age Diverse Workforce Management (SAWM) affected negatively (-5.248) when compared to the overall influence of High Work Performance Workplace Management (HPWM) and Knowledge Management Age Diverse Workforce (KMAD) that has an overall influence at 3.900 and 2.767. This study showed the weak point of organization in planning of Strategic Age Diverse Workforce Management that affected from ignorance important points or lack of knowledge of specific management. Training of awareness is a new point and the majority of training might be working knowledge training to increase efficiency, not the guideline for aging people to be successful. The training should focus on design, using material and workplace management comfortable to aging people, and taking advantage of knowledge and skills to address new challenges (Armstrong-Stassen \& Templer, 2005).

From hypothesis testing in the model showed that planning of High Work Performance Workplace Management (HPWM) and Knowledge Management Age Diverse Workforce (KMAD) affected Potential Corporate Reputation directly and indirectly. The factors of knowing culture value and social value were mediator factors and planning of age-diverse workforce in organization consisted of two aspects in this study - awareness training and communication planning to support age-diverse workforce. Because of the sample business majority as $75 \%$ were service and retail shops, they might not think it was necessary to invest to train aging people to aware of the changing mode of technology. In communication planning in the organization, the director would understand the communication as to communicate between workers or workers with an organization such over the phone. They are not planning or aware of virtual organizations that appear daily including aging people who work at home and communicate with the organization. The strong point from the model analysis found that High Work Performance Workplace Management (HPWM) and Knowledge Management Age Diverse Workforce (KMAD) influenced Potential Corporate Reputation (PCR) directly and indirectly. In the part of HPWM, because the sample business produced goods as only $25 \%$, the planning of High Work Performance Workplace Management was not important. As knowledge Management Age Diverse Workforce (KMAD) consisted of Knowledge Retention (KR), Knowledge Sharing (KS), because of Thai culture, the member in an organization might leave the organization without transferring the knowledge, based on Thai culture (Bock \& Kim, 2002; Dholakia, 2005). The different age group has a different level of knowledge, therefore, they have a role to support other (role of reciprocity), and it was an important factor that makes knowledge efficient (Sole \& Applegate, 2000; Kim et al., 2008; Bennett \& Kottasz, 2000).

\section{Conclusion}

The result of the study regarding the theory evidence and support research from overseas has a problem in applying to practice with an empirical result that differs locally. Therefore, the model needs to be verified with the local data, and develop a suitable model. This model was doubt in mediation variable; PV and SV in its role, including SAWN and PHWM factors in an organization, show that it is a highperformance organization to verify and compare in the context of age-diverse workforce management.

\section{References}

Angus, J., \& Reeve, P. (2006). Ageism: A threat to "aging well" in the 21 st century. The Journal of Applied Gerontology, 25, 137-152.

Armstrong-Stassen, M., \& Templar, A. (2005). Adapting training for older employees: The Canadian response to an aging workforce. The Journal of Management Development, 24(1/2), 57-67.

Ball, A. C., Reiss, A. E., Rudolph, C. W., \& Baltes, B. B. (2011). Examining positive and negative perceptions of older workers: A meta-analysis. The Journals of Gerontology, Series B: Psychological Sciences and Social Sciences, 66(6), 687-698.

Barney, J. (1991). Firm resources and sustained competitive advantage. Journal of Management, 17(1), 99-120. 
Beck, V. (2009). Older workers-older learners: The perspectives of employers in the east midlands. Leicester: Centre for Labour Market Studies/ Learning \& Skills Council.

Bennett, R., \& Kottasz, R. (2000). Practitioner perceptions of corporate reputation: An empirical investigation. Corporate Communications: An International Journal, 5(4), 224-234.

Bock, G. W., \& Kim, Y. G. (2002). Breaking the myths of rewards: an exploratory study of attitudes about knowledge sharing. Information Resources Management Journal, 15(2), 14-21.

Cappelli, P. (2010). New workforce management: The aging workforce and thereversal of authority. Retrieved 12 April 2012, from http://www. hiring.monster.com/hr/hr-best practices/workforce-management $/ \mathrm{hr}$ management-skills/newworkforcemanagement.aspx

Cong, X., \& Pandya, K. (2003). Issues of knowledge management in the public sector. Academic Conferences Limited, 1(2), 25-33.

Dholakia, D. (2005). The social influence of brand community: Evidence from European car clubs. Journal of Marketing, 69(3), 19-34.

Forester Research. (2012). Foresights workforce employee survey. Canada: Author.

Fombrun, C. J. (1999). Reputation: Realizing value from the corporate image. Boston: Harvard Business School Press.

Frank, R. (2003). NRC management in motion. Retrieve 23 December 2017, from https://www.gao.gov/ assets/690/684347.pdf

Green, D. (2007). Leading in a postmodern workforce. Academy of Strategic Management Journal, 6(15), 15-25.

Grubic-Nesic, M. D., \& Mitrovic, S. (2014). The influence of demographic and Organizational factors on knowledge sharing among employees in organizations. TehnickiVjesnik, 22(4), 1005-1010.

Hennig-Thurau, T., Malthouse, E. C., Friege, C., Gensler, S., Lobschat, L., Rangaswamy, A., \& Skiera, B. (2010). The impact of new media on customer relationships. Journal of Service Research, 13(3), 311-330.

Henkens, K., \& Schippers. J. (2012). Active aging in Europe: the role of organizations. International Journal of Manpower, 33(6), 604-611.

Hewitt, A. (2012). Recognizing the value of older workers. Retrieve 23 December, 2017, from https://states.aarp. org/wp-content/uploads/2015 /08/A-Business-Case-for-Older Workers-Age-50-A-Look-at-the-Value -ofExperience.pdf

Khan, H. et al. (2018). Personal goals in later life: Opportunities and innovation for an aging society. Gerontechnology, 17(suppl).

Kim, W. G., Jin Sun, B., \& Kim, H. J. (2008). Multidimensional customer-based brand equity and its consequences in mid prices hotel. Journal of Hospitality \& Tourism Research, 32 (2), 235-254.

Loomes, S., \& McCarthy, G. (2011). The aging workforce: How can Australian universities address future workforce challenges. Wellington, New Zealand: ANZAM.

Mouritsen, J. (2000). Valuing expressive organizations: Intellectual capital and the visualization of value creation. In M. Schultz, M. J. Hatch, \& M. H. Larsen (Eds.), The expressive organization: Linking identity, reputation, and the corporate brand. Oxford: Oxford University Press.

Northouse, P. G. (2013). Leadership: Theory and practice (6th ed.). Thousand Oaks, CA: Sage.

Paarlberg, L. E., \& Perry, J. L. (2007). Values management, aligning individual values and organization goals. The American Review of Public Administration, 37(4), 387-408.

Stam, C. (2009). Knowledge and the aging employee: A research agenda. Retrieve 23 December, 2017, from http://www.scienceguide.nl/pdf /Stam200906.pdf

Sole, D. L., \& Applegate, L. M. (2000). Knowledge sharing practices and technology use norms in dispersed development teams. In S. Ang, H. Krcmar, W. Orlikowski

Streb, K. C., Voelpel, C. S., \& Leibold, M. (2008). Managing the aging workforce: Status quo and implications for the advancement of theory and practice. European Management Journal, 26, 1-10.

United Nations. (2010). World population prospect: The 2010 Revision. Retrieved November 2, 2010, from http:// www.esa.un.org/peps/fertility_figures/interactive-figures_TF-trajectories.

Van Riel, C. B. M., \& Balmer, J. M. T. (1997). Corporate identity: The concept, its measurement and management. European Journal of Marketing, 31(5/6/), 340-355. 